\title{
Synthesis and Antiviral Activity of Diaza-18-crown-6 Derivatives with the Fragments of 4-Aminomethylbenzoic and 6-Aminocaproic Acids
}

\author{
Stepan S. Basok, ${ }^{\text {a }}$ Anatoliy F. Lutsyuk, ${ }^{\text {a }}{ }^{\text {Tatyana L. Gridina, }}{ }^{\mathrm{b}}$ and Alla S. Fedchuk ${ }^{\mathrm{c}}$ \\ ${ }^{a}$ A.V. Bogatsky Physico-Chemical Institute, National Academy of Sciences of Ukraine, 65080 Odessa, Ukraine \\ ${ }^{\mathrm{b}}$ Odessa National Medical University, 65026 Odessa, Ukraine \\ ${ }^{\mathrm{B}}$ BPPP Research Center, 65003 Odessa, Ukraine \\ @Corresponding authorE-mail: lutsyuk@ukr.net
}

\begin{abstract}
Among the most important properties governing wide spectrum of biological activities of crown ethers are their high lipophilicity, selectivity of the complex formation as well as ability of transporting ions and some neutral molecules across the biological membranes, similarly to the natural ionophores. Modification of diazacrown ethers by introducing fragments of known antiviral agents into their structure can be assumed to yield new products with high antiviral activity. The compounds of a class of protease inhibitors, 4-aminomethylbenzoic and 6-aminocaproic acids are of interest in respect of this. We have synthesized derivatives with free amino and carboxyl groups containing fragments of known antiviral drugs, 4-aminomethylbenzoic and 6-aminocaproic acids, based on the macrocyclic diaza-18-crown-6 platform. The cytotoxicity and antiviral activity of synthesized compounds against of human influenza strains A/Hong Kong/1/68 (H3N2) and A/Puerto Rico/8/34 (H1N1) have been studied. Synthesis of compounds with free amino group (1,10-bis(6-aminohexanoyl)-diaza-18-crown-6 and 1,10-bis(4-aminomethylbenzoyl)-diaza-18-crown-6) have been carried out by interaction of diaza-18-crown-6 with Boc-protected derivatives of 6-aminocaproic and 4-aminomethylbenzoic acids in the presence of DCC and HOBT followed by removal of the Boc-protective group in the intermediate compounds by the action of trifluoroacetic acid. It should be noted that using HOBT allowed us to avoid the formation of collateral bis-N-acylureas, simplify the purification, and increase the total yields of final products to 90-92\%. Acylation of benzyl esters of studied N,N'-dicarboxymethyldiaza-18-crown-6 amino acids was investigated to obtain the compounds with the free carboxyl group, 6,6'-\{(7,16-diaza-18-crown-6)-7,16-diylbis[(1-oxoethane-2,1-diyl)imino]\} dihexanoic acid and 4,4'-\{(7,16-diaza-18-crown-6)-7,16-diylbis[(1-oxoethane-2,1-diyl)iminomethylene]\} dibenzoic acid. In this case, using DCC as a condensing agent has resulted the main reaction product to be macrocyclic bis$N$-acylureas, and the desired compounds have not been obtained. Therefore, another method of peptide chemistry was used for the acylation of esters of the studied acids - mixed anhydride method with ethyl chloroformate. By this method the benzyl esters of dipeptides with yields of 85-87\% were obtained. Subsequent removal of the benzyl protecting group in these compounds by catalytic hydrogenolysis resulted in desired products with yields of 92-94\%. The toxicity level for all the synthesized compounds was studied on a model using Colpoda steinii infusoria culture and the chorionallantoic membrane cells of chick embryos, and antiviral activity against human influenza strains A/ Hong Kong/1/68 (H3N2) and A/Puerto Rico/8/34 (H1N1) in culture of the chorionallantoic membrane cells of chick embryos. Synthesized compounds showed significantly higher level of antiviral activity compared to that of 4-aminomethylbenzoic and 6-aminocaproic acids on both strains of the influenza virus with no cytotoxicity demonstrated in the studied concentrations. The compounds with 6-aminocaproic acid fragments were more active toward both virus strains. It should be noted that the 1,10-bis(6-aminohexanoyl)-diaza-18-crown-6 showed marked activity towards influenza A/Hong Kong/1/68 (H3N2) strain not only at a concentration of $1 \mathrm{mmol} / \mathrm{L}\left(\Delta \log 10 \mathrm{TCID}_{50}=3.9\right)$, but also at a lower dose of $0.5 \mathrm{mmol} / \mathrm{L}\left(\mathrm{Llog} 10 \mathrm{TCID}_{50}=1.17\right)$. 6,6'-\{(7,16-Diaza-18-crown-6)-7,16-diylbis[(1-oxoethane-2,1-diyl) imino]\} dihexanoic acid was the most effective against the strain of the influenza A/Puerto Rico/8/34 (H1N1) virus. It significantly suppressed the reproduction of the virus at a concentration of $0.5 \mathrm{mmol} / \mathrm{L}\left(\Delta \log 10 \mathrm{TCID}{ }_{50}=4.92\right)$. Both compounds demonstrate the level of the reference drug Oseltamivir regarding their influenza activity and are promising compounds for the further research on the in vivo models for the purpose of designing the new antiviral drugs.
\end{abstract}

Keywords: Azacrown ethers, diaza-18-crown-6, aminomethylbenzoic acid, aminocaproic acid, antiviral activity, cytotoxicity. 


\title{
Синтез и антивирусная активность производных Аиаза-18-краун-6 с фрагментами 4-аминометилбензойной и 6-аминокапроновой кислот
}

\author{
С. С. Басок, ${ }^{a}$ А. Ф. Ауцюк, ${ }^{\mathrm{@}}$ Т. А. Гридина, ${ }^{\mathrm{b}}$ А. С. Федчук \\ ${ }^{\mathrm{a}}$ Физико-химический институт им. А.В. Богатского Национальной академии наук Украинь, 65080 Одесса, Украина \\ ${ }^{\mathrm{b}}$ Одесский национальный медицинский университет, 65026 Одесса, Украина \\ 'Научно-исследовательский изентр БППП, 65003 Одесса, Украина \\ @E-mail:lutsyuk@ukr.net
}

\begin{abstract}
Синтезированы производнье диаза-18-краун-6 со свободной амино- и карбоксильной группами, содержащие фрагменты известных противовирусных препаратов - 4-аминометилбензойной и 6-аминокапроновой кислот. Для всех синтезированных соединений исследована циитотоксичность и антивирусная активность в отношении вирусов грипnа A/Hong Kong/1/68 (H3N2) и A/Puerto Rico/8/34 (H1N1) на культуре ткани хорион-аллантоисных оболочек. Синтезированные соединения показали антивирусную активность, существенно превышаюшую активность 4-аминометилбензойной и 6-аминокапроновой кислот при отсутствии ичтотоксичности в изучаемых кониентрациях. Необходимо отметить, что соединения с фрагментом 6-аминокапроновой кислоты проявляли более высокую активность по сравнению с соединениями, содержащими остаток 4-аминометилбензойной кислоть. Наибольшую активность к вирусу гриппа A/Puerto Rico/8/34 (H1N1) проявляло соединение на основе $N, N^{\prime}$-дикарбоксиметилдиаза-18-краун-6 с фрагментом 6-аминокапроновой кислоты. Оно существенно подавляло репродукцию вируса в концентрациии 0.5 ммоль/л $\left(\Delta \lg\right.$ ТИД $\left.{ }_{50}=4.92\right)$. K вирусу гриппа A/ Hong Kong/1/68 (H3N2) самым эффективнымм было производное диаза-18-краун-6 и 6-аминокапроновой кислоты в концентрации 1 ммоль/л (4lg ТИД $\left.{ }_{50}=3.9\right)$. Оба соединения по своей активности находятся на уровне референс-препарата осельтамивира.
\end{abstract}

Ключевые слова: Азакраун-эфиры, диаза-18-краун-6, аминометилбензойная кислота, аминокапроновая кислота, антивирусная активность, цитотоксичность.

\section{Введение}

Одними из важнейших свойств краун-эфиров являются их высокая липофильность, селективность комплексообразования, а также возможность осуществлять транспорт ионов и некоторых нейтральных молекул через биологические мембраны подобно природным ионофорам. Эти свойства обуславливают широкий спектр биологического действия краун-эфиров. ${ }^{[1-3]}$

В этом плане особый интерес представляют диазакраун-эфиры, свойства которых могут быть существенно изменены путем введения различных заместителей по атомам азота. Введение в молекулу диазакраун-эфиров фармакофорных фрагментов приводит к образованию веществ, обладающих интересной биологической активностью, что позволяет рассматривать их как потенциальные фармакологические препараты с широким спектром действия. В частности, комплексы диаза-18-краун-6 с солями арилхалькогенуксусных кислот, а также глицилпроизводные диаза-18-краун-6 проявляют антипролиферативную активность, ${ }^{[4,5]}$ $N$-гидроксикарбонилметил- и $N$-гидроксикарбонилпропилпроизводные бензодиаза-15-краун-5 - антимутагенное действие. ${ }^{[6]}$ Комплексы диазакраун-эфиров с $\mathrm{Fe}_{3} \mathrm{O}_{4}$ проявляют активность в отношении грамположительных и грамотрицательных микроорганизмов, ${ }^{[7]}$ бензильные производные диаза-18-краун-6 - кардиотроп- ную активность, ${ }^{[8]}$ нафтилпроизводные диазакраунэфиров - гемопоэтическую и колониестимулирующую активностость, ${ }^{[9]}$ адамантилпроизводные диаза-18краун-6 - противоопухолевую активность. ${ }^{[10,11]}$ Лариатные краун-эфиры на основе диаза-18-краун-6 обладают биологической активностью относительно бактерий E. coli, B. subtilis и S. cerevisiae, а также существенно повышают эффективность таких противомикробных препаратов, как рифампицин и тетрациклин. ${ }^{[12,13]}$ Производные краун-эфиров с фрагментами $\gamma$-аминомасляной кислоты оказывают антигипоксическое и антиамнистическое действие. При этом присутствие в их структуре краун-эфира способствует транспорту факмакофоров через гематоэнцефалический барьер. ${ }^{[14]}$ Среди краунэфиров обнаружены соединения, проявляющие широкий спектр антивирусной активности. ${ }^{[15,16]}$ Производные диаза-18-краун-6, содержащие боковые фрагменты, обладающие потенциальной биологической активностью (тиомочевины), проявляют противовирусную активность в отношении вируса гриппа H3N2. ${ }^{[17]}$

Можно предположить, что модификация диазакраун-эфиров введением в их структуру фрагментов известных антивирусных агентов может привести к созданию новых соединений с высокой антивирусной активностью. Присоединение к макроциклической платформе нескольких молекул антивирусных агентов может способствовать увеличению специфической 
биологической эффективности таких антивирусных соединений за счет эффекта концентрирования. В этом отношении представляют интерес 4-аминометилбензойная и 6-аминокапроновая кислоты - соединения класса ингибиторов протеаз, которые обладают противовирусной активностью, в частности в отношении вирусов гриппа. ${ }^{[18]}$ Они нарушают цикл репродукции вирусов гриппа H3N2 и H1N1 серотипов и подавляют образование нового вирусного поколения. ${ }^{[19]}$

Таким образом, исходя из вышеизложенного, на основе молекулярной платформы диаза-18-краун-6 нами синтезированы производные 6-аминокапроновой и 4-аминометилбензойной кислот со свободной аминои карбоксильной группами. Для всех синтезированных соединений исследована цитотоксичность и антивирусная активность в отношении вирусов гриппа H3N2 и $\mathrm{H} 1 \mathrm{~N} 1$.

\section{Экспериментальная часть}

Строение полученных соединений установлено методом ядерного магнитного резонанса на ядрах ${ }^{1} \mathrm{H}$ и ${ }^{13} \mathrm{C}$ на приборе Bruker AVANCE DRX 500 с рабочей частотой 499.87 МГц $\left({ }^{1} \mathrm{H}\right)$ и 125.69 МГц $\left({ }^{13} \mathrm{C}\right)$ для $\sim 10 \%$ растворов в ДМСО- $d_{6}$ и $\mathrm{CDCl}_{3}$, внутренний стандарт - ТМС. Масс-спектры получены методом ББА на масс-спектрометре VG 70-70EQ с использованием пучка атомов Хе с энергией $8 \mathrm{kV}$ и применением $\mathcal{M}$-нитробензилового спирта в качестве матрицы. Температуры плавления измерены в открытых капиллярах и не исправлены. Индивидуальность синтезированных соединений контролировалась методом тонкослойной хроматографии на пластинах Kieselgel 60 F254 (Merk), очистка осуществлялась методом кристаллизации или колоночной хроматографии на силикагеле (Kieselgel $600.063-0.100 \mathrm{~mm}$, Merk). Чистоту соединений определяли методом ВЭЖХ, используя хроматографическую систему SHIMADZU (контролер системы CBM-20A; вакуумный дегазатор DGU-20 A5; насос высокого давления LC-20AD UFLC, оснащенный 4-канальным градиентным блоком на низком давлении; термостат колонок CTO-20A; диодно-матричный детектор SPDM20A), оснащенную колонкой Acclaim PolarAdvantage II $3 \mu \mathrm{m}$ $(4.6 \mathrm{~mm} \times 150 \mathrm{~mm})$ с Guard-картриджем, ручным инжектором с петлёй на 10 мкл. Подвижная фаза: ацетонитрил $(30 \%)$ и $0.1 \%$ раствор трифторуксусной кислоты в деионизированной воде (70 \%). Скорость потока подвижной фазы: 1.0 мл/мин. Объем инжекции 10 мкл. Температура в термостате: $2{ }^{\circ} \mathrm{C}$. Диапазон сканирования UV-спектра: 190-400 нм. Чистота синтезированных соединений по данным ВЭЖХ составляла не менее $98.5 \%$.

\section{Синтез}

6-Вос-Аминогексановая, ${ }^{[20]}$ 4-Вос-аминометилбензойная $^{[20]}$ кислоты, бензиловые эфиры 6-аминогексановой ${ }^{[20]}$ и 4-аминометилбензойной ${ }^{[20]}$ кислот, диаза-18-краун-6 $6^{[21]}$ и $N, N^{\prime}$-бис(карбоксиметил)диаза-18-краун-6 ${ }^{[21]}$ получали как описано ранее. Их спектральные характеристики и физические константы соответствовали приведенным в литературе.

Общая методика получения 1 и 2. Метод А. К раствору 1.31 г (5 ммоль) диаза-18-краун-6 и 11 ммоль 6-Вос-аминогексановой или 4-Boc-аминометилбензойной кислоты в 15 мл безводного дихлорметана при комнатной температуре прибавляли 2.27 г (11 ммоль) $N, N^{\prime}$-дициклогексилкарбодиимида. Реакционную смесь перемешивали еще 4-5 ч (контроль окончания реакции осуществляли методом ТСХ, элюент - хлороформ:метанол:аммиак, 5:3:1) и отфильтровывали выпавшую дициклогексилмочевину. Органическую фазу последовательно промывали 0.05 н раствором соляной кислоты $(4 \times 10$ мл), водой (10 мл), раствором карбоната натрия $(4 \times 10$ мл), водой (10 мл) и сушили безводным сульфатом натрия. Растворитель отгоняли на ротационном испарителе досуха. Сырой продукт очищали методом колоночной хроматографии (элюент - этилацетат:метанол, 20:1).

Метод Б. К раствору 11 ммоль 6-Вос-аминогексановой или 4-Вос-аминометилбензойной кислоты, 1.49 г (11 ммоль) 1-гидроксибензотриазола в 5 мл безводного диоксана и 15 мл безводного дихлорметана при комнатной температуре прибавляли 2.27 г (11 ммоль) $N, N^{\prime}$-дициклогексилкарбодиимида. Смесь перемешивали на магнитной мешалке в течение 1 ч, прибавляли 5 ммоль (1.31 г) диаза-18-краун-6, перемешивали еще 4-5 ч (контроль окончания реакции осуществляли с помощью метода ТСХ, элюент - хлороформ:метанол:аммиак, 5:3:1) и отфильтровывали выпавшую дициклогексилмочевину. Органическую фазу последовательно промывали 0.05 н раствором соляной кислоты $(4 \times 10$ мл), водой $(10$ мл), раствором карбоната натрия ( $4 \times 10$ мл), водой (10 мл) и сушили безводным сульфатом натрия. Растворитель упаривали при пониженном давлении досуха. Сырой продукт очищали методом колоночной хроматографии (элюент - этилацетат:метанол, 20:1).

1,10-Бис (6-Вос-аминогексаноил)диаза-18-краун-6 (1). Метод А - выход $72 \%$. Метод Б - выход $95 \%$. Светложелтое кристаллическое вещество. Т.пл. $79-82{ }^{\circ} \mathrm{C} . R_{f}=0.76$ (хлороформ:метанол:аммиак, 5:3:1). $m / z$ (ББА): $689(\mathrm{M}+\mathrm{H})^{+} .{ }^{1} \mathrm{H}$ ЯMP $\left(\mathrm{CDCl}_{3}\right) \delta_{\mathrm{H}}$ м. д.: $1.32\left(4 \mathrm{H}, \mathrm{M}, \mathrm{CH}_{2}\right), 1.41\left(18 \mathrm{H}, \mathrm{c}, \mathrm{C}\left(\mathrm{CH}_{3}\right)_{3}\right)$, $1.47\left(4 \mathrm{H}, \mathrm{м}, \mathrm{CH}_{2}\right), 1.60\left(4 \mathrm{H}, \mathrm{m}, \mathrm{CH}_{2}\right), 2.30\left(4 \mathrm{H}, \mathrm{m}, \mathrm{CH}_{2}\right), 3.09(4 \mathrm{H}$, м, $\left.\mathrm{CH}_{2}\right), 3.60\left(24 \mathrm{H}, \mathrm{м}, \mathrm{CH}_{2} \mathrm{O}\right), 4.61(2 \mathrm{H}$, уш. с, $\mathrm{NH}) .{ }^{13} \mathrm{C}$ ЯМР $\left(\mathrm{CDCl}_{3}\right) \delta_{\mathrm{C}}$ м.д.: $24.88\left(2 \mathrm{C}, \mathrm{CH}_{2}\right), 26.58\left(2 \mathrm{C}, \mathrm{CH}_{2}\right), 28.43(6 \mathrm{C}$, $\left.\mathrm{CH}_{3}\right), 29.90\left(2 \mathrm{C}, \mathrm{CH}_{2}\right), 32.89\left(2 \mathrm{C}, \mathrm{CH}_{2}\right), 40.38\left(2 \mathrm{C}, \mathrm{CH}_{2}\right), 46.96$ $\left(2 \mathrm{C}, \mathrm{CH}_{2} \mathrm{~N}\right), 48.76\left(2 \mathrm{C}, \mathrm{CH}_{2} \mathrm{~N}\right), 69.55\left(2 \mathrm{C}, \mathrm{CH}_{2} \mathrm{O}\right), 69.98(2 \mathrm{C}$, $\left.\mathrm{CH}_{2} \mathrm{O}\right), 70.38\left(2 \mathrm{C}, \mathrm{CH}_{2} \mathrm{O}\right), 70.82\left(2 \mathrm{C}, \mathrm{CH}_{2} \mathrm{O}\right), 78.97\left(2 \mathrm{C}, \mathrm{CCH}_{3}\right)$, $156.02(2 \mathrm{C}, \mathrm{CONH}), 173.08(2 \mathrm{C}, \mathrm{CON})$.

1,10-Бис(4-Вос-аминометилбензоил)диаза-18-краун-6 (2). Метод А - выход $69 \%$. Метод Б - выход $94 \%$. Белое кристаллическое вещество. Т.пл. $120-122{ }^{\circ} \mathrm{C} . \quad R_{f}=0.69$ (хлороформ:метанол:аммиак, 5:3:1). $m / z$ (ББА): $729(\mathrm{M}+\mathrm{H})^{+} .{ }^{1} \mathrm{H}$ ЯMР $\left(\mathrm{CDCl}_{3}\right) \delta_{\mathrm{H}}$ м.д.: $1.43\left(18 \mathrm{H}, \mathrm{c}, \mathrm{C}\left(\mathrm{CH}_{3}\right)_{3}\right), 3.53\left(16 \mathrm{H}\right.$, м, $\left.\mathrm{CH}_{2} \mathrm{O}\right)$, $3.76\left(8 \mathrm{H}, \mathrm{м}, \mathrm{CH}_{2} \mathrm{O}\right), 4.28\left(4 \mathrm{H}\right.$, д $J=6.0$ Гц, $\left.\mathrm{ArCH}_{2} \mathrm{~N}\right), 4.93(2 \mathrm{H}$, уш. c, NH), 7.25 (4H, д $J=7.5$ Гц, ArH), 7.30 (4H, д $J=8.1$ Гц, ArH).

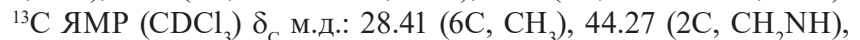
$46.31\left(2 \mathrm{C}, \mathrm{CH}_{2} \mathrm{~N}\right), 49.91\left(2 \mathrm{C}, \mathrm{CH}_{2} \mathrm{~N}\right), 69.83\left(4 \mathrm{C}, \mathrm{CH}_{2} \mathrm{O}\right), 70.59(4 \mathrm{C}$, $\left.\mathrm{CH}_{2} \mathrm{O}\right), 79.70\left(2 \mathrm{C}, \mathrm{CCH}_{3}\right), 126.91$ (4C, Ar), 127.37 (4C, $\left.\mathrm{Ar}\right), 135.60$ (2C, Ar), 140.39 (2C, Ar), 155.94 (2C, CONH), 172.02 (2C, CON).

Общая методика получения производных 3 и 4. К раствору 3.3 ммоль 1 или 2 в 10 мл безводного хлороформа при перемешивании на магнитной мешалке при $0{ }^{\circ} \mathrm{C}$ прибавляли 0.78 мл (10 ммоль) трифторуксусной кислоты. Реакционную смесь перемешивали 1 ч, растворитель отгоняли на ротационном испарителе досуха при температуре не более $40{ }^{\circ} \mathrm{C}$. Полученный остаток растворяли в 10 мл воды, подщелачивали 50 \%-ым раствором $\mathrm{NaOH}$ до $\mathrm{pH}$ 9-10 и экстрагировали хлороформом (7×10 мл). Объединенные хлороформные экстракты сушили безводным сульфатом магния, растворитель упаривали досуха. Полученный остаток растворяли в 10 мл безводного этилацетата и прибавляли при охлаждении 3 мл 4 н раствора $\mathrm{HCl}$ в этилацетате. Выпавший продукт $\mathbf{4}$ отфильтровывали, а продукт 3 после удаления этилацетата при пониженном давлении выделяли в виде масла, которое сушили в вакууме до постоянного веса.

1,10-Бис(6-аминогексаноил)диаза-18-краун-6 дигидрохлорид (3). Выход 96 \%. Маслообразное вещество светло-желтого цвета. $R_{f}=0.61$ (хлороформ:метанол:аммиак, 5:3:1). $\mathrm{m} / \mathrm{z}$ (ББА): $489(\mathrm{M}+\mathrm{H})^{+} .{ }^{1} \mathrm{H}$ ЯМР (ДМСО- $\left.d_{6}\right) \delta_{\mathrm{H}}$ м.д.: $1.25(4 \mathrm{H}$, м, $\left.\mathrm{CH}_{2}\right), 1.34\left(4 \mathrm{H}, \mathrm{м}, \mathrm{CH}_{2}\right), 1.46\left(4 \mathrm{H}, \mathrm{м}, \mathrm{CH}_{2}\right), 2.28\left(4 \mathrm{H}, \mathrm{м}, \mathrm{CH}_{2}\right)$, 
$2.55\left(4 \mathrm{H}\right.$, м, $\left.\mathrm{CH}_{2}\right), 3.47\left(24 \mathrm{H}\right.$, м, $\left.\mathrm{CH}_{2} \mathrm{O}\right) .{ }^{13} \mathrm{C}$ ЯМР (ДМСО- $\left.d_{6}\right)$

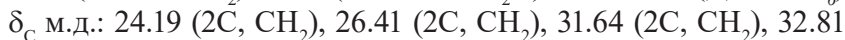
$\left(2 \mathrm{C}, \mathrm{CH}_{2}\right), 40.86\left(2 \mathrm{C}, \mathrm{CH}_{2}\right), 47.25\left(2 \mathrm{C}, \mathrm{CH}_{2} \mathrm{~N}\right), 49.30\left(2 \mathrm{C}, \mathrm{CH}_{2} \mathrm{~N}\right)$, $69.07\left(2 \mathrm{C}, \mathrm{CH}_{2} \mathrm{O}\right), 69.46\left(2 \mathrm{C}, \mathrm{CH}_{2} \mathrm{O}\right), 70.03\left(2 \mathrm{C}, \mathrm{CH}_{2} \mathrm{O}\right), 70.31(2 \mathrm{C}$, $\left.\mathrm{CH}_{2} \mathrm{O}\right), 173.83(2 \mathrm{C}, \mathrm{CON})$.

1,10-Бис(4-аминометилбензоил)диаза-18-краун-6 дигидрохлорид (4). Выход 96 \%. Белое гигроскопическое кристаллическое вещество. Т.пл. $181-184{ }^{\circ} \mathrm{C} . \quad R_{f}=0.55$ (хлороформ:метанол:аммиак, 5:3:1). $\mathrm{m} / z$ (ББА): $529(\mathrm{M}+\mathrm{H})^{+} .{ }^{1} \mathrm{H}$ ЯМР (ДМСО- $\left.d_{6}\right) \delta_{\mathrm{H}}$ м.д.: $3.53\left(24 \mathrm{H}, \mathrm{м}, \mathrm{CH}_{2} \mathrm{O}\right), 4.02(2 \mathrm{H}, \mathrm{c}, \mathrm{NH})$, $4.04\left(4 \mathrm{H}\right.$, д $J=6.1$ Гц, $\left.\mathrm{ArCH}_{2} \mathrm{~N}\right), 7.39$ (4H, д $J=8.4$ Гц, $\left.\mathrm{ArH}\right), 7.56$

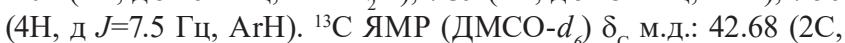
$\left.\mathrm{CH}_{2} \mathrm{NH}_{2}\right), 46.64\left(2 \mathrm{C}, \mathrm{CH}_{2} \mathrm{~N}\right), 50.15\left(2 \mathrm{C}, \mathrm{CH}_{2} \mathrm{~N}\right), 68.44\left(2 \mathrm{C}, \mathrm{CH}_{2} \mathrm{O}\right)$, $68.79\left(2 \mathrm{C}, \mathrm{CH}_{2} \mathrm{O}\right), 69.82\left(2 \mathrm{C}, \mathrm{CH}_{2} \mathrm{O}\right), 70.02\left(2 \mathrm{C}, \mathrm{CH}_{2} \mathrm{O}\right), 127.00$ (4C, Ar), 129.23 (2C, Ar), 134.42 (2C, Ar), 135.87 (4C, Ar), 173.97 $(2 \mathrm{C}, \mathrm{CON})$.

Общая методика получения производных 5 и 6. К смеси 3.78 г (10 ммоль) измельченного $N, N^{\prime}$-бис(карбоксиметил) диаза-18-краун-6 и 2.8 мл (20 ммоль) триэтиламина в 15 мл безводного хлороформа при $0{ }^{\circ} \mathrm{C}$ прибавляли по каплям 2.17 г (30 ммоль) хлорэтилкарбоната. Реакционную смесь перемешивали 25-30 мин при $0{ }^{\circ} \mathrm{C}$ и прикапывали раствор 20 ммоль бензилового эфира соответствующей аминокислоты в 20 мл безводного хлороформа. Перемешивание продолжали еще 3 ч, температура реакционной смеси при этом постепенно повышалась до комнатной. Реакционную смесь оставляли на ночь. Затем прибавляли 10-15 мл хлороформа, полученный хлороформный раствор промывали последовательно водой $(3 \times 10$ мл), $3 \%$ раствором гидрокарбоната натрия $(2 \times 10$ мл), водой $(2 \times 10$ мл) и сушили безводным сульфатом натрия. Растворитель упаривали досуха, продукт очищали методом колоночной хроматографии (элюент - метанол:триэтиламин, 5:0.01).

Бензиловыйэфир 6,6'-\{(7,16-диаза-18-краун-6)-7,16диилбис[(1-оксоэтан-2,1-диил)имино]\}дигексановой кислоть (5). Выход $85 \%$. Маслообразное вещество светло-желтого цвета. $R_{f}=0.37$ (хлороформ:метанол:аммиак, 5:3:1). $\mathrm{m} / z$ (ББА): $785(\mathrm{M}+\mathrm{H})^{+} .{ }^{1} \mathrm{H}$ ЯМР $\left(\mathrm{CDCl}_{3}\right) \delta_{\mathrm{H}}$ м.Д.: $1.30\left(4 \mathrm{H}, \mathrm{M}, \mathrm{CH}_{2}\right), 1.48(4 \mathrm{H}$, м, $\left.\mathrm{CH}_{2}\right), 1.61\left(4 \mathrm{H}, \mathrm{m}, \mathrm{CH}_{2}\right), 2.29\left(4 \mathrm{H}, \mathrm{c}, \mathrm{COCH}_{2} \mathrm{~N}\right), 2.30(4 \mathrm{H}, \mathrm{M}$, $\left.\mathrm{CH}_{2}\right), 2.81\left(4 \mathrm{H}, \mathrm{м}, \mathrm{CH}_{2}\right), 3.20\left(8 \mathrm{H}, \mathrm{м}, \mathrm{CH}_{2} \mathrm{O}\right), 3.55\left(16 \mathrm{H}, \mathrm{м}, \mathrm{CH}_{2} \mathrm{O}\right)$, $5.07\left(4 \mathrm{H}, \mathrm{c}, \mathrm{ArCH}_{2}\right), 7.32(10 \mathrm{H}, \mathrm{м}, \mathrm{ArH}) .{ }^{23} \mathrm{C}$ ЯMP $\left(\mathrm{CDCl}_{3}\right) \delta_{\mathrm{C}}$ м.д.: $24.61\left(2 \mathrm{C}, \mathrm{CH}_{2}\right), 26.50\left(2 \mathrm{C}, \mathrm{CH}_{2}\right), 29.30\left(2 \mathrm{C}, \mathrm{CH}_{2}\right), 34.13(2 \mathrm{C}$, $\left.\mathrm{CH}_{2}\right), 38.96\left(2 \mathrm{C}, \mathrm{CH}_{2}\right), 55.46\left(4 \mathrm{C}, \mathrm{CH}_{2} \mathrm{~N}\right), 66.11\left(2 \mathrm{C}, \mathrm{ArCH}_{2} \mathrm{O}\right)$, $66.16\left(2 \mathrm{C}, \mathrm{CH}_{2} \mathrm{~N}\right), 68.65\left(4 \mathrm{C}, \mathrm{CH}_{2} \mathrm{O}\right), 70.34\left(4 \mathrm{C}, \mathrm{CH}_{2} \mathrm{O}\right), 127.93$ (2C, Ar), 128.15 (4C, Ar), 128.56 (4C, Ar), 136.04 (2C, Ar), 171.18 (2C, $\mathrm{CON}), 173.40$ (2C, COO).

Бензиловый эфир 4,4'-\{(7,16-диаза-18-краун-6)-7,16диилбис[(1-оксоэтан-2,1-диил)иминометилен]\}дибензойной кислоты (6). Выход 87 \%. Белое кристаллическое вещество. Т.пл. $103-105{ }^{\circ} \mathrm{C} . R_{f}=0.73$ (хлороформ:метанол:аммиак, 5:3:1). $m / z$ (ББА): $825(\mathrm{M}+\mathrm{H})^{+} .{ }^{1} \mathrm{H}$ ЯМР $\left(\mathrm{CDCl}_{3}\right) \delta_{\mathrm{H}}$ м.д.: $2.55(8 \mathrm{H}, \mathrm{M}$, $\left.\mathrm{CH}_{2} \mathrm{O}\right), 3.16\left(4 \mathrm{H}, \mathrm{c}, \mathrm{COCH}_{2} \mathrm{~N}\right), 3.33\left(16 \mathrm{H}, \mathrm{M}, \mathrm{CH}_{2} \mathrm{O}\right), 4.48(4 \mathrm{H}$, д $J=6.0$ Гц, $\left.\mathrm{ArCH}_{2} \mathrm{~N}\right), 5.34\left(4 \mathrm{H}, \mathrm{c}, \mathrm{ArCH}_{2}\right), 7.34(10 \mathrm{H}, \mathrm{м}, \mathrm{ArH})$, 7.42 (4H, д $J=8.2$ Гц, ArH), 7.99 (4H, д $J=8.2$ Гц, ArH), 8.30 (2H, уш.с, NH). ${ }^{13} \mathrm{C}$ ЯМР $\left(\mathrm{CDCl}_{3}\right) \delta_{\mathrm{C}}$ м.д.: $42.63\left(2 \mathrm{C}, \mathrm{CH}_{2} \mathrm{NH}\right), 55.74$ $\left(4 \mathrm{C}, \mathrm{CH}_{2} \mathrm{~N}\right), 58.86\left(2 \mathrm{C}, \mathrm{CH}_{2} \mathrm{~N}\right), 66.69\left(2 \mathrm{C}, \mathrm{ArCH}_{2} \mathrm{O}\right), 68.94(4 \mathrm{C}$, $\left.\mathrm{CH}_{2} \mathrm{O}\right), 70.32$ (4C, $\left.\mathrm{CH}_{2} \mathrm{O}\right), 127.37$ (4C, $\left.\mathrm{Ar}\right), 128.22$ (4C, $\left.\mathrm{Ar}\right), 128.31$ (2C, Ar), 128.62 (4C, Ar), 128.93 (2C, Ar), 129.89 (4C, Ar), 136.03 (2C, Ar), 144.58 (2C, Ar), 166.19 (2C, CON), 172.12 (2C, COO).

Общая методика получения производных 7 и 8 . В колбу для каталитического гидрирования при перемешивании на магнитной мешалке помещали 0.125 г $10 \% \mathrm{Pd} / \mathrm{C}, 50$ мл безводного метанола и активировали водородом в течение 1 ч при комнатной температуре и атмосферном давлении. Затем вносили раствор 5 ммоль 5 или 6 в 20 мл безводного метанола и продолжали гидрирование в течение 10 ч (контроль окончания реакции осуществляли методом ТСХ, система ацетон:гексан, 1:2). Катализатор отфильтровывали, про- мывали 20 мл безводного метанола, растворитель отгоняли на ротационном испарителе досуха, полученный остаток сушили в вакууме до постоянного веса.

6,6'-\{(7,16-Диаза-18-краун-6)-7,16-диилбис[(1-оксоэтан2,1-диил)имино]; дигексановая кислота (7). Выход $92 \%$. Маслообразное вещество светло-желтого цвета. $R_{f}=0.51$ (ацетон:гексан, 1:2). $\mathrm{m} / \mathrm{z}$ (ББА): $605(\mathrm{M}+\mathrm{H})^{+} .{ }^{1} \mathrm{H}$ ЯМР (ДМСО- $d_{6}$ ) $\delta_{\mathrm{H}}$ м.д.: $1.25\left(4 \mathrm{H}, \mathrm{м}, \mathrm{CH}_{2}\right), 1.39\left(4 \mathrm{H}, \mathrm{м}, \mathrm{CH}_{2}\right), 1.48\left(4 \mathrm{H}, \mathrm{м}, \mathrm{CH}_{2}\right)$, $2.18\left(4 \mathrm{H}, \mathrm{м}, \mathrm{CH}_{2}\right), 2.28\left(4 \mathrm{H}\right.$, уш. с, $\left.\mathrm{COCH}_{2} \mathrm{~N}\right), 2.63\left(4 \mathrm{H}, \mathrm{м}, \mathrm{CH}_{2}\right)$, $3.06\left(8 \mathrm{H}, \mathrm{м}, \mathrm{CH}_{2} \mathrm{O}\right), 3.49\left(16 \mathrm{H}, \mathrm{м}, \mathrm{CH}_{2} \mathrm{O}\right) .{ }^{13} \mathrm{C}$ ЯMP (ДМСО- $\left.d_{6}\right)$

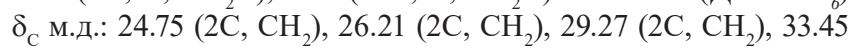
$\left(2 \mathrm{C}, \mathrm{CH}_{2}\right), 39.10\left(2 \mathrm{C}, \mathrm{CH}_{2}\right), 55.67\left(4 \mathrm{C}, \mathrm{CH}_{2} \mathrm{~N}\right), 65.12\left(2 \mathrm{C}, \mathrm{CH}_{2} \mathrm{~N}\right)$, $68.54\left(4 \mathrm{C}, \mathrm{CH}_{2} \mathrm{O}\right), 70.13\left(4 \mathrm{C}, \mathrm{CH}_{2} \mathrm{O}\right), 171.18(2 \mathrm{C}, \mathrm{CON}), 174.71$ (2C, $\mathrm{COO})$.

4,4'-\{(7,16-Диаза-18-краун-6)-7,16-диилбис[(1-оксоэтан2,1-диил)иминометилен]; дибензойная кислота (8). Выход $94 \%$. Маслообразное вещество светло-желтого цвета. $R_{f}=0.59$ (ацетон:гексан, 1:2). $m / z$ (ББА): $645(\mathrm{M}+\mathrm{H})^{+} .{ }^{1} \mathrm{H}$ ЯМР $\left(Д \mathrm{MCO}-d_{6}\right) \delta_{\mathrm{H}}$ м.д.: $2.75\left(8 \mathrm{H}, \mathrm{м}, \mathrm{CH}_{2} \mathrm{O}\right), 3.16\left(4 \mathrm{H}, \mathrm{c}, \mathrm{COCH}_{2} \mathrm{~N}\right)$, $3.45\left(16 \mathrm{H}, \mathrm{м}, \mathrm{CH}_{2} \mathrm{O}\right), 4.42\left(4 \mathrm{H}\right.$, д $J=6.0$ Гц, $\left.\mathrm{ArCH}_{2} \mathrm{~N}\right), 7.47(4 \mathrm{H}$, д $J=7.5$ Гц, ArH), 8.05 (4Н, д $J=7.5$ Гц, ArH). ${ }^{13} \mathrm{C}$ ЯМР (ДМСО- $d_{6}$ )

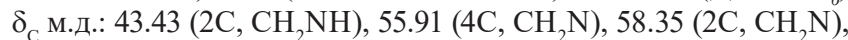
$68.63\left(4 \mathrm{C}, \mathrm{CH}_{2} \mathrm{O}\right), 70.29$ (4C, $\left.\mathrm{CH}_{2} \mathrm{O}\right), 127.25$ (4C, $\left.\mathrm{Ar}\right), 128.75(2 \mathrm{C}$, Ar), 129.63 (4C, Ar), 144.26 (2C, Ar), 166.57 (2C, CON), 174.48 (2C, COO).

\section{Методики изучения токсичности синтезированных соединений}

Mетод A (на культуре инфузорий Colpoda steinii). Для изучения токсичности исследуемых соединений на культуре инфузорий Colpoda steinii раскрывали два флакона с сухой культурой Colpoda steinii производства предприятия «Возрождение-М» $\left(\right.$ Одесса, Украина) ${ }^{[22]}$ и один флакон с питательной средой. В каждый флакон с высушенной культурой Colpoda steinii прибавляли по 2 мл питательной среды, флаконы закрывали и термостатировали при температуре $26-28^{\circ} \mathrm{C}$ в течение 24 ч. Затем культуру Colpoda steinii выдерживали 15 мин на свету и наблюдали движение одноклеточных под световым микроскопом, используя метод висячей капли (при увеличении $\times$ 80-150). Для подтверждения жизнеспособности культуры в поле зрения должно было присутствовать не менее 6 клеток инфузорий, которые активно двигались. Во флаконы с активной культурой вносили 2 мл исследуемых растворов изучаемых соединений и перемешивали. В контрольный флакон с активной культурой Colpoda steinii вносили 2 мл питательной среды. Критерием определения токсичности служило время от начала воздействия испытуемых соединений на культуру инфузорий Colpoda steinii до гибели большинства (90 \% и более) колпод, которая констатировалась на основании полного прекращения движения колпод и наличия их распада. В контрольной пробе все колподы должны были оставаться подвижными. Токсичными считали разведения веществ, при прибавлении которых гибель инфузорий наступала в интервале до 10 мин наблюдения. Слаботоксичные - до 3 ч наблюдения. Нетоксичными считались разведения, в которых через 3 ч наблюдения все простейшие оставались подвижными. ${ }^{[22]}$

Метод Б (на культуре ткани хорион-аллантоисных оболочек). Токсичность изучаемых соединений на культуре ткани хорион-аллантоисных оболочек (ХАО) 11-14-суточных куриных эмбрионов определяли стандартным методом. ${ }^{[23]} \mathrm{C}$ этой целью их навески растворяли в ДМСО (конечная концентрация ДМСО не превышала 1 \%), а затем разводили на глюкозо-желатиновой поддерживающей среде, в концентрациях 100, 50, 10, 5 и 1 ммоль/л, в которой культивировали фрагменты ткани ХАО. Глюкозо-желатиновая поддерживающая среда содержала $4 \%$ фосфатного буфера, 4 \% глюкозы, 1 \% желатина и антибиотиков. ${ }^{[24]}$ Уровень $\mathrm{pH}$ поддерживающей среды должен был 
составлять 7.2-7.4, поэтому перед проведением экспериментов обязательно проверяли $\mathrm{pH}$ поддерживающей среды, доводя этот показатель, при необходимости, до физиологического значения. Каждое разведение препаратов добавляли в 5 лунок 72-луночных полистироловых панелей, в которые помещали фрагменты ХАО, прикрепленные к скорлупе. После 48 часов термостатирования тканевой культуры при $37^{\circ} \mathrm{C}$ регистрировали наличие или отсутствие цитотоксического действия. Минимальной токсической дозой (МТД концентрация препарата, которая вызывала гибель 50 и более процентов фрагментов ХАО.

\section{Методика определения противогриппозной активности синтезированных соединений}

Противогриппозную активность препаратов in vitro в отношении вируса гриппа человека штаммов A/Hong Kong/1/68 (H3N2) и A/Puerto Rico/8/34 (H1N1) изучали на культуре ткани ХАО 11-12 дневных куриных эмбрионов, поскольку эту культуру можно считать наиболее приближенной к уровню целого организма, которым является куриный эмбрион.[23]

Для изучения противовирусного действия химических соединений на репродукцию вируса гриппа на тканевой культуре ХАО их растворяли, как описано выше, в ДМСО, а затем на поддерживающей среде, доводя, при необходимости, уровень $\mathrm{pH}$ до физиологического значения.

С целью изучения противовирусного действия препаратов использовали вируссодержащую аллантоисную жидкость, которую предварительно накапливали в аллантоисной полости куриных эмбрионов, с агглютинирующей активностью не ниже $1: 1024$ и инфекционной активностью не ниже $7.0 \lg$ ТИД. . Эту вируссодержащую жидкость, разводили на глюкозо-желатиновой поддерживающей среде таким образом, чтобы содержание вирусных частиц в заражающем материале было не ниже $100 \lg$ ТИД . При этом поддерживающая среда содержала (опыт) или не содержала (контроль) исследуемый препарат. Десятикратными разведениями этого вируссодержащего материала от $10^{-1}$ до $10^{-6}$ инфицировали фрагменты ХАО, прикрепленные к скорлупе, которые располагали в полистирольных 72-луночных планшетах. Исследования проводили в пяти повторах. После термостатирования при $37^{\circ} \mathrm{C}$ в течение 24 часов контрольные и опытные образцы отдельно объединялись, и в них проводили определение титра инфекционного вируса. С этой целью десятикратными разведениями этих образцов инфицировали фрагменты ХАО в полистирольных планшетах. После 48 часов термостатирования при $37^{\circ} \mathrm{C}$ определяли титр вируса по результатам реакции гемагглютинации (РГА) с $1 \%$ взвесью куриных эритроцитов. ${ }^{[23]}$

Расчет ТИД 50 в экспериментах in vitro проводили методом Кербера в модификации Ашмарина ${ }^{[25]}$ по формуле:

$$
\lg \text { ТИД }_{50}=L-d(\mathrm{~S}-0.5),
$$

где $L$ - начальное разведение в опыте; $d$ - разница между последовательными $\lg$ разведений; $S$ - сумма пропорций тест-объектов, которые дали положительный результат. Статистическую значимость антивирусной активности соединений определяли по непараметрическому критерию знаков для связанных выборок. ${ }^{[26]}$

В качестве референс-препарата использовали осельтамивир - порошок «Тамифлю» фирмы «F. Hoffmann La-Roche» (Швейцария) для приготовления суспензии для приема внутрь по 12 мг в 1 мл во флаконе по 30 мл, который применяли в концентрации 410 мкг/мл, что соответствует 1 ммоль/л.

\section{Результаты и обсуждение}

\section{Синтез}

Первоначально попытка синтеза целевых соединений 3 и 4 со свободной аминогруппой взаимодействием диаза-18-краун-6 с Вос-защищенными производными 6-аминокапроновой и 4-аминометилбензойной кислот с помощью карбодиимидного метода, как было описано нами ранее, ${ }^{[27]}$ привела к промежуточным соединениям с выходами $69 \%$ и $72 \%$, соответственно. Полной конверсии диаза-18-краун-6 удалось достичь при 15-20\% избытке Вос-6-аминокапроновой кислоты и 20-30 \% Boc-4-аминометилбензойной кислоты. Реакционная смесь в этом случае кроме целевых продуктов 1 и 2 содержала значительную примесь $N$-ацилированных мочевин, что существенно затрудняло очистку промежуточных продуктов методом колоночной хроматографии.

Поэтому с целью оптимизации метода синтеза Восзамещенных промежуточных соединений 1 и 2 нами был использован $N, N^{\prime}$-дициклогексилкарбодиимид в присутствии широко применяемой в пептидном синтезе нуклеофильной добавки - $N$-гидроксибензотриазола. Применение последнего позволило избежать образования побочных $N$-ацилмочевин и, соответственно, упростить очистку и повысить выходы конечных продуктов до 94-96 \%. Удаление Вос-защитной группы в промежуточных соединениях трифторуксусной кислотой ${ }^{[20]}$ в безводном хлороформе приводило к трифторацетатам соединений 3 и 4, которые с помощью стандартных процедур переводили в соответствующие дигидрохлориды (Схема 1).

Для получения соединений со свободной карбоксильной группой нами осуществлено ацилирование бензиловых эфиров исследуемых аминокислот $N, N^{\prime}$-дикарбоксиметилдиаза-18-краун-6. Применение
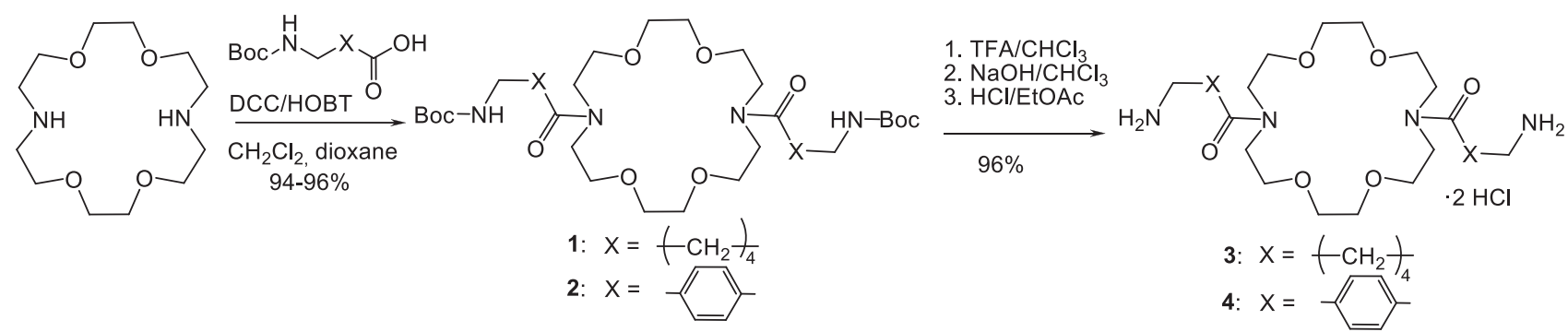

\section{Схема 1.}


$N, N$ '-дициклогексилкарбодиимида в качестве конденсирующего агента, в данном случае, привело к тому, что основными продуктами реакции были макроциклические бис- $N$-ацилмочевины, а желаемые соединения так и не были получены. Изменение соотношения исходных реагентов и условий проведения реакции к положительным результатам не привели.

В связи с этим, для ацилирования эфиров исследуемых кислот нами был применен другой метод пептидной химии - метод смешанных ангидридов с этилхлоркарбонатом. ${ }^{[28]} \mathrm{C}$ помощью этого метода были получены бензиловые эфиры дипептидов (5 и 6) с выходами 85 \% и $87 \%$, соответственно (Схема 2).

Последующее удаление бензильной защитной группы в промежуточных соединениях 5 и 6 каталитическим гидрогенолизом позволило получить целевые соединения 7 и 8 со свободными карбоксильными группами с выходами $92 \%$ и 94 \%, соответственно.

\section{Определение противовирусной активности исследуемых препаратов}

Перед изучением противовирусной активности синтезированных соединений была проверена их токсичность двумя параллельными методами - на культуре инфузорий Colpoda steinii ${ }^{[22]}$ и тканевой культуре $\mathrm{XAO}^{[23]}$ (Таблица 1). Соединения $\mathbf{3 , 4}$ и 8 не проявляли токсического действия как к Colpoda steinii, так и на тканевой культуре ХАО в концентрации 1 ммоль/л, a $7-0.5$ ммоль/л. Поэтому их противогриппозную активность исследовали в этих концентрациях.

Результаты противогриппозной активности изучаемых препаратов in vitro по снижению уровня репродукции вируса гриппа людей штаммов A/Hong Kong/1/68 (H3N2) и A/Puerto Rico/8/34 (H1N1) на тканевой культуре $\mathrm{XAO}^{[23]}$ представлены в Таблице 1.

Исходные 4-аминометилбензойная и 6-аминокапроновая кислоты в концентрации 1 ммоль/л проявляли очень низкую активность в отношении обоих изученных штаммов по сравнению с референспрепаратом осельтамивиром, который подавлял репродукцию обоих штаммов на $\Delta \lg$ ТИД $=4.17$ в той же концентрации. Соединения 4 и 7 проявляли незначительную противогриппозную активность в отношении штамма A/Hong Kong/1/68 (H3N2). Наиболее активным оказалось соединение 3 на основе диаза-18-краун-6 с фрагментом 6-аминокапроновой кислоты. Оно показало выраженную противогриппозную активность $\left(\Delta \lg\right.$ ТИД $\left._{50}=3.9\right)$ на культуре ткани ХАО не только в концентрации 1 ммоль/л, но и в более низкой -0.5 ммоль/л $\left(\Delta \lg\right.$ ТИД $\left._{50}=1.17\right)$.

В отношении вируса гриппа штамма A/Puerto Rico/8/34 (H1N1) соединения 3, 4 и 8 проявляли незначительную противогриппозную активность. Самым эффективным к этому штамму вируса гриппа на куль-

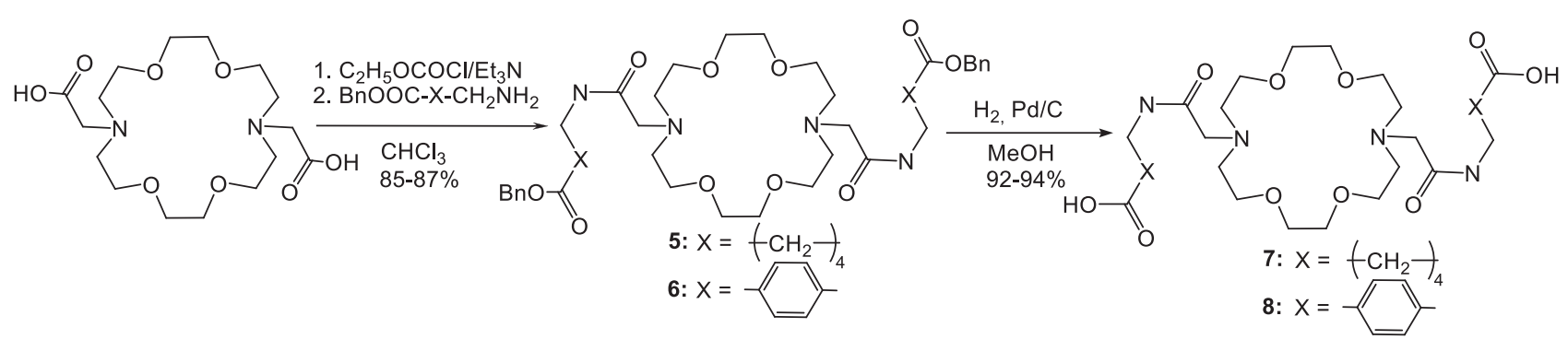

Схема 2.

Таблица 1. Токсичность и противогриппозная активность изучаемых препаратов.

\begin{tabular}{|c|c|c|c|c|c|}
\hline \multirow{2}{*}{ Вещество } & \multirow{2}{*}{$\begin{array}{c}\text { Нетоксическая } \\
\text { концентрация } \\
\text { на Colpoda steinii } \\
\text { (ммоль/л) }\end{array}$} & \multirow{2}{*}{$\begin{array}{c}\text { МТД }_{50} \\
\text { на ХАО } \\
\text { (ммоль/л) }\end{array}$} & \multirow{2}{*}{$\begin{array}{c}\text { Изучаемая } \\
\text { концентрация } \\
\text { препаратов } \\
\text { (ммоль/л) }\end{array}$} & \multicolumn{2}{|c|}{$\begin{array}{c}\text { Средний показатель подавления репродукции } \\
\left.\text { вируса штаммов (в } \Delta \lg \text { ТИД }{ }_{50}\right)\end{array}$} \\
\hline & & & & $\begin{array}{c}\text { A/Hong Kong/1/68 } \\
\text { (H3N2) }\end{array}$ & $\begin{array}{c}\text { A/Puerto Rico/8/34 } \\
\text { (H1N1) }\end{array}$ \\
\hline \multirow{2}{*}{3} & 1 & 10 & 1 & $3.9 \pm 0.2$ & $0.92 \pm 0.20$ \\
\hline & 0.5 & 10 & 0.5 & $1.17 \pm 0.10$ & - \\
\hline 4 & 1 & 10 & 1 & $1.0 \pm 0.2$ & $0.25 \pm 0.10$ \\
\hline 7 & 0.5 & 10 & 0.5 & $0.92 \pm 0.10$ & $4.92 \pm 0.20$ \\
\hline 8 & 1 & 10 & 1 & $0.3 \pm 0.1$ & $1.1 \pm 0.1$ \\
\hline $\begin{array}{c}\text { 6-аминокапроновая } \\
\text { кислота }\end{array}$ & 1 & 1000 & 1 & $0.15 \pm 0.10$ & $0.33 \pm 0.20$ \\
\hline $\begin{array}{c}\text { 4-аминометил- } \\
\text { бензойная кислота }\end{array}$ & 1 & 500 & 1 & $0.05 \pm 0.01$ & $\mathrm{H} / \mathrm{a}$ \\
\hline осельтамивир & 1 & 10 & 1 & $4.17 \pm 0.30$ & $4.17 \pm 0.20$ \\
\hline
\end{tabular}


туре ткани ХАО в концентрации 0.5 ммоль/л было соединение 7 также с фрагментом 6-аминокапроновой кислоты на платформе $N, N$ '-дикарбоксиметилдиаза-18краун-6 $\left(\Delta \lg\right.$ ТИД $\left._{50}=4.92\right)$.

Необходимо отметить, что соединения с фрагментом 6-аминокапроновой кислоты проявляли более высокую активность по сравнению с соединениями, содержащими остаток 4-аминометилбензойной кислоты. Наибольшую активность в отношении штамма A/Hong Kong/1/68 (H3N2) проявляло соединение со свободной аминогруппой (3), а по отношению к штамму A/Puerto Rico/8/34 (H1N1) - со свободной карбоксильной (7). Оба соединения по своей активности находятся на уровне референс-препарата осельтамивира.

\section{Выводы}

Синтезированы производные диаза-18-краун-6 со свободной амино- и карбоксильной группами, содержащие фрагменты известных противовирусных препаратов - 4-аминометилбензойной и 6-аминокапроновой кислот. Для всех синтезированных соединений исследована цитотоксичность и антивирусная активность в отношении вируса гриппа человека штаммов A/Hong Kong/1/68 (H3N2) и A/Puerto Rico/8/34 (H1N1) на культуре ткани хорион-аллантоисных оболочек куриных эмбрионов.

Установлено, что синтезированные соединения по своей активности существенно превосходят 4-аминометилбензойную и 6-аминокапроновую кислоты, а наибольшую активность к данным штаммам вируса при отсутствии цитотоксического действия в изучаемых концентрациях проявляют соединения $\mathbf{3}$ и 7 с фрагментами 6-аминокапроновой кислоты. Соединение 3 на основе диаза-18-краун-6 показало выраженную противогриппозную активность к штамму вируса гриппа A/Hong Kong/1/68 (H3N2) ( $\Delta \lg \quad$ ТИД $\left.{ }_{50}=3.9\right)$ не только в концентрации 1 ммоль/л, но и в более низкой концентрации - 0.5 ммоль/л $\left(\Delta \lg\right.$ ТИД $\left.{ }_{50}=1.17\right)$. Производное $N, N^{\prime}$-дикарбоксиметилдиаза-18-краун-6 (7) существенно подавляло репродукцию вируса гриппа A/Puerto Rico/8/34 (H1N1) в концентрации 0.5 ммоль/л $\left(\Delta \lg\right.$ ТИД $\left._{50}=4.92\right)$. Данные вещества по своей активности находятся на уровне референс-препарата осельтамивира и являются перспективными для дальнейшего их исследования на моделях in vivo с целью создания новых противовирусных препаратов.

\section{References}

1. Alfonso I., Quesada R. Chem. Sci. 2013, 4, 3009-3019.

2. Liu T., Bao C., Wang H., Fei L., Yang R., Long Y., Zhu L. New J. Chem. 2014, 38, 3507-3513.

3. Kralj M., Tušek-Božić L., Frkanec L. ChemMedChem 2008, 3, 1478-1492.

4. Adamovich S.N., Mirskova A.N., Mirskov R.G., Perminova O.M., Chipanina N.N., Aksamentova T.N., Voronkov M.G. Russ. J. Gen. Chem. 2010, 80, 1007-1010.
5. Marjanović M., Kralj M., Supek F., Frkanec L., Piantanida I., Šmuc T., Tušek-Božić L. J. Med. Chem. 2007, 50, 1007-1018.

6. Zasukhina G.D., Vasil'eva I.M., Vedernikov A.I., Gromov S.P., Alfimov M.V. Bull. Exp. Biol. Med. 2006, 3(141), 331-333.

7. Hasanova U.A., Ramazanov M.A., Maharramov A.M., Gakhramanov Z., Hajiyeva S.F., Vezirova L., Eyvazova G.M., Hajiyeva F.V., Huseynova P., Agamaliyev Z. J. Inclusion Phenom. Macrocyclic Chem. 2016, 86(1-2), 19-25.

8. Gurbanov K.G., Paperno A.A., Spasov A.A., Vasil'ev P.M., Breslaukhov A.G., Luk'ianenko N.G., Basok S.S., Kulygina E.Iu., Bogashchenko T.Iu. Eksp. Klin. Farmakol. 1993, 56(3), 32-34.

9. Samiei E.F., Boojar M.M.A., Moradi-Sardareh H. J. Inclusion Phenom. Macrocyclic Chem. 2017, 87, 259-266.

10. Supek F., Ramljak T.Š., Marjanović M., Buljubašić M., Kragol G., Ilić N., Šmuc T., Zahradka D., Mlinarić-Majerski K., Kralj M. Eur. J. Med. Chem. 2011, 46, 3444-3454.

11. Guberović I., Marjanović M., Mioč M., Ester K., MartinKleiner I., Ramljak T.Š., Mlinarić-Majerski K., Kralj M. Sci. Rep. 2018, 8(1), 14467.

12. Cantwell R., Garrad E.C., Gokel M.R., Hayes M.J., Meisel J.W., Negin S., Patel M.B., Gokel G.W. Curr. Org. Chem. 2015, 19, 2229-2236.

13. Negin S., Patel M.B., Gokel M.R., Meisel J.W., Gokel G.W. ChemBioChem 2016, 17, 2153-2161.

14. Karaseva T.L., Tsapenko J.M., Basok S.S. Ukr. Bioorg. Acta 2012, 10(2), 9-12.

15. Ivanov É.I., Polishchuk A.A., Boreko E.I., Vladyko G.V., Korobchenko L.V. Pharm. Chem. J. 1988, 22, 560-563.

16. Lozitsky V., Basok S., Fedchuk A., Shitikova L., Mudrik L., Gridina T. Antivir. Res. 2006, 70(1), A49.

17. Zabirov N.G., Pozdeev O.K., Shcherbakova V.A., Shumilova T.N., Gil'manova G.K., Cherkasov R.A. Pharm. Chem. J. 1990, 24, 661-663.

18. Kiselev O.I. Chemo Drugs and Chemotherapy Flu. St. Petersburg: Rostok, 2011. 272 р. (in Russ.) [Киселев О.И. Химиопрепараты и химиотерапия гриппа. Санкт-Петербург: Росток, 2011. 272 c.]

19. Lozitsky V.P. In: National Institute of Allergology and Infectious Diseases, NIH. Vol. 1 Frontiers in Research (Georgiev V.S., Western K.A., McGowan J.J., Eds.). Humana Press, 2008. p. 193-198.

20. Bodanszky M. Principles of Peptide Synthesis. New York: Springer Science \& Business Media, 2012. 308 p.

21. Kulstad S., Malmsten L.Å. Acta Chem. Scand. 1979, 33b, 469-474.

22. Lozytskyi V.P., Hryhorasheva I.M., Fedchuk A.S., Hrydina T.L., Boshchenko Yu.A., Slavina N.H. Patent of Ukraine 15629 A, 2006.

23. In: Preclinical Studies of Drugs. Kyiv: Avicena, 2002. p. 395-420 [В кн.: Доклинические исследования лекарственных средств. Киев: Авицена, 2002. с. 395-420].

24. Serkedjieva J. Phytother. Res. 2004, 18, 480-483.

25. Ashmarin I.P. Zh. Mikrobiol. 1959, 2, 102-108 (in Russ.).

26. Gubler E.V., Genkin A.A. [Application of Non-Parametric Criteria of Statistics in Biomedical Research]. Leningrad: Meditsina, 1973. 144 p. (in Russ.) [Гублер Е.В., Генкин А.А. Применение непараметрических критериев статистики в медико-биологических исследованиях. Л.: Медицина, 1973. 144 c.].

27. Lukyanenko N.G., Bogatskii A.V., Basok S.S., Ostrovskaya L.K., Nazarova N.Y., Karpenko L.P. Zh. Org. Khim. 1984, 20, $1580-1587$ (in Russ.).

28. Montalbetti C.A., Falque V. Tetrahedron 2005, 61, 1082710852. 